\title{
EFFECT OF MAGNETIC TREATED WATER ON PRODUCTIVE AND REPRODUCTIVE PERFORMANCE OF BALADY RABBIT DOES AND THEIR OFFSPRING
}

\author{
Ayat A. Ragab and Yasmim M.M. Mahmoud \\ Animal Production Research Institute, Agriculture Research Center, Dokki, Giza
}

(Received 11/9/2015, accepted 1/11/2015)

\section{SUMMARY}

\begin{abstract}
$\mathrm{T}$ Thirty black balady rabbit does aged 7 to 8 months old with averaged live body weight (LBW) $3125 \pm 60.49 \mathrm{~g}$ were used in a complete randomized design and were randomly assigned into three homogeneous groups (10 does in each). The first group was drinking tap water and regarded as control group (G1), while the second (G2) and third (G3) groups were drinking a magnetic treated water with 1200 and 3600 gauss, respectively. Rabbits in all groups were fed the commercial rabbit diet. Results showed that magnetic treated water (MTW) had better quality than those for tap water (TW) in conductivity, salinity and total hardness. Does in G2 drink magnetic water (1200 gauss) showed significantly $(\mathrm{P}<0.05)$ the highest live body weight (LBW) at mating and kindling, $1^{\text {st }}$ service conception rate and the lowest number of services per conception, followed by those in G3 drink magnetic water (3600 gauss), while those in G1 drink tap water had the poorest values. Moreover, does in G2 recorded significantly $(\mathrm{P}<0.05)$ the highest average daily milk yield (ADMY) at different suckling intervals, followed by those in G3, while those in G1 had the lowest yield. Also, does in G2 significantly $(P<0.05)$ the highest percentages of fat, protein, TS and SNF in milk followed by those in G3, while those in G1 had the lowest percentages. While, lactose percentage in milk of does in G2 and G3 was higher significantly $(\mathrm{P}<0.05)$ than in milk of does in G1. Does in G3 showed significantly $(\mathrm{P}<0.05)$ the highest concentrations of total protein, globulin, total lipids, triglycerides and LDL, and those in G2 had the highest glucose concentration, while those in G1 recorded the highest albumin, urea-N, HDL concentrations and ALT activity. The concentrations of creatinine and total cholesterol and AST activity was not significantly affected by magnetic water. Concentrations of IgG and IgM in serum of does and their offspring were higher in G3, followed by G2, while they lower in G1, but the differences were not significant. Does in $\mathrm{G} 2$ showed significantly $(\mathrm{P}<0.05)$ the highest litter size during the different suckling intervals, followed by those in G3, while those in G1 had the lowest values. However, mortality rate revealed the opposite trend. Group G2 showed significantly $(\mathrm{P}<0.05)$ the highest weight and weight gain of litter and bunnies followed by G3, while G1 had the lowest values. Feed intake and feed cost was nearly similar for different groups. While, total cost (feed cost plus magnetic water cost) was higher significantly $(\mathrm{P}<0.05)$ for G3 followed by G2, while G1 had the lower cost. Group G2 showed significantly $(\mathrm{P}<0.05)$ the highest price of weaning weight and net revenue followed by G3, while G1 had the lowest values.
\end{abstract}

Keywords: Rabbit does, magnetic water, reproductive, productive, offspring.

\section{INTRODUCTION}

Although water is often overlooked and not considered as a nutrient when formulating rations, it is still extremely important to animal and composes about 71 to $73 \%$ of the fat free animal body weight. Water is involved in numerous vital functions. It acts as a solvent for many different biological systems such as digestion, wastes excretion, temperature regulation and transport of nutrients, hormones and oxygen. Water makes up over $98 \%$ of all molecules in the body and is necessary for production, growth, lactation, digestion, electrolytes balance, lubrication of joints, eyesight and as a cleaning agent (Lardy and Stolltenow, 1999).

In literature, the magnetic technology has been investigated in the agriculture with major emphasis on plant fields, but little attention has been given to the animal and poultry sector (Hozayn and Abdul Qados, 2010). Water is needed for every biological reaction and for transportation of every compound, cellular integrity and body temperature regulation, etc. Birds generally drink approximately twice as much water as the amount of feed consumed on a weight basis and low quality water has been shown to influence 


\section{Ragab and Mahmoud}

animal performance and to increase health threat (Marai et al., 2005; Attia et al., 2013). Moreover, De Blas (2013) reported that the alteration in the gut compositional changes has been showed as a possible cause of gut disorder and retard growth and health problem in rabbits. Recent evidences indicated that magnetic treatment of water may offer a possible solution to improve water quality (Verma, 2011).

A magnetic treatment changes mineral content of water, decreases lime deposition microbial load in the pipes and thus increases their permeability through biological membranes (Lam, 2001). An enhancement in the calves and sheep growth and a reduction in carcass fat in sheep were demonstrated due to magnetizing of water (Bergsrud and Linn, 1990). In addition, Lin and Yotvat (1989) cited that an increase in milk yield of dairy cattle consuming magnetic water. Verma (2011) reported that magnetized water stops the growth of bacteria and works as antibiotic, take care of pain, swelling and weakness and enhances overall general health. On the other hand, a contradictory result was reported by Sargolzehi et al. (2009) who showed that magnetic water did not positively affect animal performance, carcass composition, blood glucose and urea and $\mathrm{Na}, \mathrm{K}, \mathrm{Mg}$ and $\mathrm{P}$ in blood and nutrient profiles in milk such as protein, fat, lactose, non-fat solid and total solid of lambs and goats. Contact of water with a permanent magnet for a considerable time produced magnetic charges and magnetic properties. Such magnetically treated water can decrease microbial load and improve the immune system (Lam, 2001). Exposing of water to a magnetic field may offer a solution to improve reproductive performance, function of liver, renal and ovary and antioxidant status of doe rabbits and their litters. This treatment may be useful management practice in the area where rabbit farms depends on well water as a source of drinking water (El-Hanoun et al., 2013). Thus, this study aims to evaluate the effects of magnetic treatment of tap and well water on productive and reproductive performance of balady rabbit does, milk yield and composition, blood parameters and immunity status and growth of their offspring's up to weaning.

\section{MATERIALS AND METHODS}

The current work was carried out at Sakha Animal Production Research Station, Animal Production Research Institute, Agricultural Research Center, Ministry of Agriculture during the period from March to May 2015.

Thirty black balady rabbit does aged 7 to 8 months old with averaged live body weight (LBW) $3125 \pm 60.49 \mathrm{~g}$ were used in a complete randomized design and were randomly assigned into three homogeneous groups (10 does in each). The first group was drinking tap water and regarded as control group (G1), while the second (G2) and third (G3) groups were drinking a magnetic treated water with 1200 and 3600 gauss, respectively. All animals were subjected to tap and magnetic water as drinking water for 30 days before starting the experimental design. Magnetic treated water was prepared by passing water through a magnetic funnel 12 at relatively low speed. According to the product specification, water will keep its magnetic properties for the next 12 hour of exposure to the funnel. So, water was supplied to the animal's cages each 10 hours to ensure using magnetic treated drinking water. Funnel's magnetic field consists of seven pairs of successive magnets. Each magnet had a circle shape with a diameter and thickness of 7.22 and $4.96 \mathrm{~mm}$, respectively. The strength of the magnet was between 1200 to 3600 Gauss as measured by a gauss meter (Mega Dev, Inc). Sample preparation attention was paid to avoid contamination, therefore every item from the moment of sampling until analysis was regarded as potential source of contamination and was checked not to contain or leach detectable amount of any contaminant. Rabbits in all groups were fed the commercial rabbit diet to cover their requirements according to NRC (1977). Ingredients and chemical composition of the control diet are presented in Table (1). Chemical analysis of diet was determined according to AOAC (1995).

Rabbits were housed separately in individual wired cages $(30 \times 50 \times 30 \mathrm{~cm})$ and arranged in double tier batteries allocated in two rows till insemination. After insemination, rabbits were placed again in individual cages $(50 \times 60 \times 35 \mathrm{~cm}$ ) of galvanized wire net and arranged in double tier batteries allocated in two rows. Nest boxes $(30 \times 25 \times 30 \mathrm{~cm})$ were attached to the front sides of the cages five days prior to kindling and removed at 30 days of lactation (weaning age). The bucks were housed in individual cages as that of females, but without nest boxes. All cages were equipped with feeders (made of galvanized steel sheets) and nipples (automatic drinkers). The system provided animals with fresh water all over the experimental period. Rabbits in all treatment groups were kept under similar managerial system and environmental conditions.

Doe rabbits were individually weighed at the mating and kidding. Does were naturally inseminated using four balady bucks rabbit fed the control diet. Pregnancy diagnosis was done by palpation at 10 - 
12 days post-mating and does failed to conceive post $1^{\text {st }}$ mating was reinseminated and number of services per conception was calculated. During the suckling period, milk yield was determined by the differences in LBW before and after suckling and milk composition was determined using milko-scan (Model 133B).

Table (1). Formulation and composition of commercial rabbit diet

\begin{tabular}{|c|c|c|c|}
\hline Ingredient & $\%$ & Composition & $\%$ \\
\hline Berseem hay & 30 & $\mathrm{DM}$ & 88.06 \\
\hline Wheat bran & 16 & $\mathrm{OM}$ & 90.57 \\
\hline Soybean meal & 20 & $\mathrm{CP}$ & 16.54 \\
\hline Yellow corn & 20 & $\mathrm{CF}$ & 12.33 \\
\hline Barley grain & 10 & $\mathrm{EE}$ & 2.25 \\
\hline molasses & 2 & NFE & 59.45 \\
\hline limestone & 1 & Ash & 9.43 \\
\hline Common salt & 0.5 & & \\
\hline Premix $*$ & 0.5 & & \\
\hline Total & 100 & & \\
\hline
\end{tabular}

Post-kindling, litter size and weight were recorded for each group at birth and at weekly intervals up to weaning at 30 days. Feed intake and weight gain during pregnancy and lactation and kindling rate of does as well as litter size and weights, stillbirths and mortality rate of bunnies were also recorded.

Blood samples were taken from does and their offspring at the end of suckling period from ear vein into clean sterile tubes. Blood samples were let to coagulate and centrifuged at $3500 \mathrm{rpm}$ for 15 minutes and serum was separated and stored at $-20{ }^{\circ} \mathrm{C}$ till assay. Concentrations of total protein, albumin, globulin (by difference), creatinine, urea nitrogen, glucose, total cholesterol, HDL, LDL (by difference), triglycerides, total lipids and activity of aspartate (AST) and alanine (ALT) aminotransferases were determined in blood serum using spectrophotometer (Spectronic 21 DUSA) and commercial kits (Combination Pasteur Lap.). Also, concentration of immunoglobulins (IgG and $\operatorname{IgM}$ ) was determined in serum of does and offspring using rabbit immunoglobulin M Elsa Kits.

Data were statistically analyzed using general linear models (GLM) procedures adapted by IBM SPSS statistics 22 (2013) for user's guide with one-way ANOVA. Duncan test within SPSS program was done to determine the degree of significance level among means.

\section{RESULTS AND DISCUSSIONS}

\section{Water Quality:}

Results in Table (2) indicated that magnetic treated water (MTW) had better quality than those for tap water (TW) in conductivity, salinity and total hardness, both water types were improved due to magnetic field exposure. The magnetic exposure resulted was in higher effect on MW than TW such as of $\mathrm{pH}(7.53$ vs. 7.68 and 7.97), Viscosity (cst) (0.794 vs. 0.792 and0.790), salinity (360 vs. 390 and $400 \mathrm{Mg} / \mathrm{L}$ ) and dissolved oxygen $(51.5$ vs. $72.5(\mathrm{mg} / \mathrm{L}))$. Total count of bacteria $(2.86,2.83$ and 2.80$)$. The tap water and there was an improvement in water quality when exposed to the magnetic field with considerable changes in the $\mathrm{pH}$, conductivity, salinity, total hardness and dissolved oxygen. Physically, exposure water to magnetic field changes water properties which becomes more energized, active, soft and high $\mathrm{pH}$ toward slight alkaline and free of germs which fulfill water quality for poultry requirements (Mg-Therapy, 2000). Magnetized water causes the hydrogen-oxygen bond angle within the water molecule to be reduced from 104 to 103 degrees. This in turn causes the water molecule to cluster together in groups of 6-7 rather than 10-12. The smaller cluster leads to better absorption of water across cell walls (Verma, 2011). Normal water has a $\mathrm{pH}$ level of about 7 , whereas magnetized water can reach $\mathrm{pH}$ of 7.8 while cancer cells do not survive well in an alkaline environment (Lam, 2001). It was reported that water passed through the magnetic field acquires finer and more homogeneous structure (Tkachenko and Semyonova, 1995). This 


\section{Ragab and Mahmoud}

increasing fluidity, dissolving capacity of various constituents like minerals and vitamins (Kronenberg, 1985 ) and consequently improving the biological activity of solutions positively affecting the performance of human being, animal and plants (Al-Mufarrej et al., 2005).

Table (2). Chemical Analysis and total count of bacteria of ordinary and magnetically treated water used in the experiment.

\begin{tabular}{lccc}
\hline Physical properties & Tap water & 1200 (Gauss) & 3600 (Gauss) \\
\hline PH & 7.53 & 7.68 & 7.79 \\
Electrical conductivity $(\mu \mathrm{s} / \mathrm{cm})$ & 498 & 503 & 507 \\
Oxygen content $(\mathrm{mg} / \mathrm{l})$ & 51.5 & 72.5 & 80.4 \\
Surface tension $(\mathrm{Dyn} / \mathrm{cm})$ & 66.56 & 58.89 & 51.11 \\
Chloride concentration $(\mathrm{ppm})$ & 61.24 & 52.12 & 41.22 \\
Viscosity $(\mathrm{cst})$ & 0.794 & 0.792 & 0.790 \\
Evaporating temperature $(\mathrm{ppm})$ & 0.75 & 0.72 & 0.70 \\
Salinity Mg/L & 360 & 390 & 400 \\
Total bacterial count $(\mathrm{CFU})$ & 2.86 & 2.83 & 2.80 \\
\hline
\end{tabular}

\section{Reproductive performance of does:}

Reproductive traits of does rabbit are shown in Table (3). Results showed that does in G2 drink magnetic water $(1200$ gauss) showed significantly $(\mathrm{P}<0.05)$ the highest live body weight $(\mathrm{LBW})$ at mating and kindling, $1^{\text {st }}$ service conception rate and the lowest number of services per conception, followed by those in G3 drink magnetic water (3600 gauss), while those in G1 drink tap water had the poorest values. However, gestation period length was nearly similar for all treatment groups, ranging from 30.3 to 31.4 days. The improved of reproductive traits of doe rabbits were concurred with increasing health status of rabbits. Similar effects were also shown in liver and renal functions and ovarian hormones. The present results are in line with those reported by Sunmonu and Oloyede (2007); Attia et al., (2013). El-Hanoun et al. (2013) found that magnetic exposure resulted in lower ( $\mathrm{P} \leq 0.05)$ number of service per conception and greater $(\mathrm{P} \leq 0.05)$ conception rate than those for the unexposed water.

Table (3). Reproductive traits of does rabbit in experimental groups.

\begin{tabular}{lcccc}
\hline \multirow{2}{*}{ Item } & \multicolumn{3}{c}{ Experimental group } & \multirow{2}{*}{ MSE } \\
\cline { 2 - 4 } & $\mathrm{G} 1$ & $\mathrm{G} 2$ & $\mathrm{G} 3$ & \\
\hline No. of does & 10 & 10 & 10 & \\
LBW at mating (g) & $2978 \mathrm{~b}$ & $3311 \mathrm{a}$ & $3089 \mathrm{ab}$ & 60.49 \\
LBW at kindling (g) & $3014 \mathrm{~b}$ & $3424 \mathrm{a}$ & $3203 \mathrm{ab}$ & 65.68 \\
Conception rate \% & & & & \\
$1^{\text {st }}$ service & $40 \mathrm{ab}$ & $50 \mathrm{a}$ & $30 \mathrm{~b}$ & 9.10 \\
$2^{\text {nd }}$ service & $20 \mathrm{~b}$ & $20 \mathrm{~b}$ & $30 \mathrm{a}$ & 7.85 \\
$3^{\text {rd }}$ service & 20 & 20 & 20 & 7.43 \\
$4^{\text {th }}$ service & $20 \mathrm{a}$ & $10 \mathrm{~b}$ & $20 \mathrm{a}$ & 6.92 \\
No. service/conception & $2.2 \mathrm{a}$ & $1.9 \mathrm{~b}$ & $2.3 \mathrm{a}$ & 0.22 \\
Gestation period (day) & 30.9 & 30.5 & 31.4 & 0.21 \\
\hline
\end{tabular}

$a, b$ : Values in the same row with different superscripts differ significantly $(P<0.05)$.

\section{Milk yield and composition:}

Results in Table (4) showed that does in G2 drink magnetic water (1200 gauss) recorded significantly $(\mathrm{P}<0.05)$ the highest average daily milk yield (ADMY) at different suckling intervals, followed by those in G3 drink magnetic water (3600 gauss), while those in G1 drink tap water had the lowest yield. Overall mean of daily milk yield during the suckling period significantly $(\mathrm{P}<0.05)$ increased by 37.25 and $15.69 \%$ for G2 and G3 compared with G1, respectively. These results agreed with those obtained by El-Hanoun et al. (2013) who found that exposure of water to the magnetic field increased $(\mathrm{P} \leq 0.05)$ milk yield compared to those of does drank un magnetized water. 
Milk composition of does including the percentages of fat, protein, lactose, total solids (TS), solids not fat (SNF) and ash are presented in Table (4). Results showed that does in G2 drink magnetic water (1200 gauss) significantly $(\mathrm{P}<0.05)$ the highest percentages of fat, protein, TS and SNF in milk followed by those in G3 drink magnetic water (3600 gauss), while those in G1 drink tap water had the lowest percentages. Moreover, lactose percentage in milk of does in G2 and G3 was higher significantly $(\mathrm{P}<0.05)$ than in milk of does in G1. While, ash percentage was not affected by drinking magnetic water. These results agreed with those obtained by El-Hanoun et al. (2013) who found doe rabbits drank magnetic water yielded milk containing greater $(\mathrm{P} \leq 0.05)$ values of fat, lactose, and energy than those drank untreated water.

Table (4). Milk yield and composition of doe rabbits at different suckling periods.

\begin{tabular}{|c|c|c|c|c|}
\hline \multirow{2}{*}{$\begin{array}{l}\text { Suckling period } \\
\text { (week) }\end{array}$} & \multicolumn{3}{|c|}{ Experimental group } & \multirow{2}{*}{ MSE } \\
\hline & G1 & G2 & G3 & \\
\hline \multicolumn{5}{|l|}{ Milk yield (g/day) } \\
\hline 1 & $99 b$ & $109 \mathrm{a}$ & $101 \mathrm{~b}$ & 9.88 \\
\hline 2 & $94 \mathrm{~b}$ & $133 \mathrm{a}$ & $130 \mathrm{a}$ & 8.75 \\
\hline 3 & $130 \mathrm{~b}$ & $181 \mathrm{a}$ & $155 \mathrm{ab}$ & 10.75 \\
\hline 4 & $90 \mathrm{~b}$ & $140 \mathrm{a}$ & $99 b$ & 9.57 \\
\hline Mean & $102 b$ & $140 \mathrm{a}$ & $118 \mathrm{ab}$ & 5.61 \\
\hline \multicolumn{5}{|l|}{$\begin{array}{l}\text { Milk composition \%: } \\
\text { Fat }\end{array}$} \\
\hline 1 & $8.70 \mathrm{~b}$ & $11.30 \mathrm{a}$ & $10.16 \mathrm{ab}$ & 1.17 \\
\hline 2 & $11.52 \mathrm{a}$ & $11.54 \mathrm{a}$ & $8.76 \mathrm{~b}$ & 1.42 \\
\hline 3 & $10.18 b$ & $11.40 \mathrm{a}$ & $11.24 \mathrm{a}$ & 1.46 \\
\hline 4 & $8.08 \mathrm{~b}$ & $9.95 \mathrm{a}$ & $10.08 \mathrm{a}$ & 1.17 \\
\hline Mean & $9.70 \mathrm{~b}$ & $11.11 \mathrm{a}$ & $10.06 \mathrm{ab}$ & 0.65 \\
\hline \multicolumn{5}{|l|}{ Protein } \\
\hline 1 & $16.12 b$ & $16.36 \mathrm{~b}$ & $18.18 \mathrm{a}$ & 0.63 \\
\hline 2 & $14.82 \mathrm{~b}$ & $15.48 \mathrm{ab}$ & $16.22 \mathrm{a}$ & 0.44 \\
\hline 3 & $16.78 \mathrm{ab}$ & $17.94 \mathrm{a}$ & $16.14 b$ & 0.66 \\
\hline 4 & $16.25 \mathrm{ab}$ & $18.63 \mathrm{a}$ & $15.36 \mathrm{~b}$ & 0.91 \\
\hline Mean & $15.98 \mathrm{~b}$ & $17.02 \mathrm{a}$ & $16.48 \mathrm{ab}$ & 0.33 \\
\hline \multicolumn{5}{|l|}{ Lactose } \\
\hline 1 & 4.44 & 4.86 & 4.50 & 0.16 \\
\hline 2 & $3.98 \mathrm{~b}$ & $4.58 \mathrm{a}$ & $4.88 \mathrm{a}$ & 0.24 \\
\hline 3 & $3.42 \mathrm{~b}$ & $4.80 \mathrm{a}$ & $4.34 \mathrm{ab}$ & 0.25 \\
\hline 4 & $3.70 \mathrm{~b}$ & $4.93 \mathrm{a}$ & $4.68 \mathrm{ab}$ & 0.23 \\
\hline Mean & $3.89 \mathrm{~b}$ & $4.78 \mathrm{a}$ & $4.60 \mathrm{a}$ & 0.11 \\
\hline \multicolumn{5}{|l|}{ Total solids } \\
\hline 1 & $30.36 \mathrm{~b}$ & $33.93 \mathrm{a}$ & $34.23 \mathrm{a}$ & 1.31 \\
\hline 2 & $31.72 b$ & $33.00 \mathrm{a}$ & $31.27 \mathrm{~b}$ & 1.33 \\
\hline 3 & $31.78 \mathrm{c}$ & $35.54 \mathrm{a}$ & $33.12 b$ & 1.92 \\
\hline 4 & $29.44 c$ & $34.91 \mathrm{a}$ & $31.53 b$ & 1.57 \\
\hline Mean & $30.98 \mathrm{c}$ & $34.31 \mathrm{a}$ & $32.54 \mathrm{~b}$ & 0.76 \\
\hline \multicolumn{5}{|l|}{ Solids not fat } \\
\hline 1 & $21.96 \mathrm{~b}$ & 22.63ab & $24.07 \mathrm{a}$ & 0.72 \\
\hline 2 & $20.20 \mathrm{~b}$ & $21.46 \mathrm{ab}$ & $22.51 \mathrm{a}$ & 0.51 \\
\hline 3 & $21.60 \mathrm{~b}$ & $24.14 \mathrm{a}$ & $21.88 \mathrm{~b}$ & 0.71 \\
\hline 4 & $21.36 \mathrm{~b}$ & $24.96 a$ & $21.45 b$ & 1.00 \\
\hline Mean & $21.27 b$ & $23.21 \mathrm{a}$ & $22.48 \mathrm{ab}$ & 0.37 \\
\hline \multicolumn{5}{|l|}{ Ash } \\
\hline 1 & 1.40 & 1.41 & 1.39 & 0.01 \\
\hline 2 & 1.40 & 1.40 & 1.41 & 0.01 \\
\hline 3 & 1.40 & 1.40 & 1.40 & 0.01 \\
\hline 4 & 1.41 & 1.41 & 1.41 & 0.01 \\
\hline Mean & 1.40 & 1.40 & 1.40 & 0.01 \\
\hline
\end{tabular}

$a, b, c$ : Values in the same row with different superscripts differ significantly $(P<0.05)$. 


\section{Ragab and Mahmoud}

\section{Blood parameters:}

Blood serum parameters of does shown in Table (5) revealed that drinking magnetic water resulted in significant differences $(\mathrm{P}<0.05)$ in the concentrations of total protein, albumin, globulin, urea-N, glucose, total lipids, triglycerides, HDL and LDL. While, the concentrations of creatinine and total cholesterol were nearly similar and not significantly affected by magnetic water. Does in G3 drink magnetic water 3600 gauss showed significantly $(\mathrm{P}<0.05)$ the highest concentrations of total protein, globulin, total lipids, triglycerides and LDL, and those in G2 drink magnetic water 1200 gauss had the highest glucose concentration, while those in G1 drink tap water recorded the highest albumin, urea-N and HDL concentrations.

Activity of AST was not significantly affected by magnetic water. While, ALT activity decreased with drinking magnetic water, which it was higher significantly $(\mathrm{P}<0.05)$ in $\mathrm{G} 1$ drinking tap water (Table 5). One could explain the enhanced biological performance, function of liver, kidney, ovary and antioxidants enzymes based on the effect of magnetic treatments to improving solubility of minerals of water, which facilities the transfer of the nutrients via improving membrane permeability to animal cells, thus nutrients uptakes and utilization as the water is the media for all biological and metabolic reactions. Furthermore, magnetic treatment was found to improve water quality, reduce lime deposition in pipes and bacterial load (Skeldon, 1990; Sargolzehi et al., 2009). Khudiar and Ali (2012) revealed that drinking of magnetic water had beneficial effect on some physiological aspects manifested by a significant elevation in serum HDL and total serum proteins concentration. In addition to significant suppression in serums total cholesterol, triacylglycerol and LDL concentrations.

Table (5). Blood serum parameters of does in different groups.

\begin{tabular}{lcccc}
\hline \multirow{2}{*}{ Item } & \multicolumn{3}{c}{ Experimental group } & \multirow{2}{*}{ MSE } \\
\cline { 2 - 3 } & $\mathrm{G} 1$ & $\mathrm{G} 2$ & $\mathrm{G} 3$ & \\
\hline Total protein $(\mathrm{g} / \mathrm{dl})$ & $6.13 \mathrm{~b}$ & $6.15 \mathrm{~b}$ & $7.45 \mathrm{a}$ & 0.27 \\
Albumin (g/dl) & $3.49 \mathrm{a}$ & $2.79 \mathrm{~b}$ & $3.34 \mathrm{a}$ & 0.12 \\
Globulin (g/dl) & $2.64 \mathrm{~b}$ & $3.36 \mathrm{ab}$ & $4.11 \mathrm{a}$ & 0.26 \\
Creatinine (mg/dl) & 0.76 & 0.80 & 0.76 & 0.08 \\
Urea-N (mg/dl) & $7.83 \mathrm{a}$ & $5.86 \mathrm{~b}$ & $4.36 \mathrm{c}$ & 0.73 \\
Glucose (g/dl) & $75.04 \mathrm{~b}$ & $98.06 \mathrm{a}$ & $73.09 \mathrm{~b}$ & 5.65 \\
Total lipids (mg/dl) & $404.53 \mathrm{~b}$ & $336.57 \mathrm{c}$ & $459.55 \mathrm{a}$ & 57.59 \\
Triglycerides (mg/dl) & $44.90 \mathrm{~b}$ & $45.09 \mathrm{~b}$ & $50.15 \mathrm{a}$ & 3.28 \\
Total cholesterol (mg/dl) & 157.25 & 156.47 & 154.51 & 2.64 \\
HDL (mg/dl) & $72.72 \mathrm{a}$ & $69.53 \mathrm{~b}$ & $60.84 \mathrm{c}$ & 9.89 \\
LDL (mg/dl) & $84.53 \mathrm{c}$ & $86.94 \mathrm{~b}$ & $93.67 \mathrm{a}$ & 8.17 \\
Activity of AST (IU/L) & 80.97 & 77.77 & 79.47 & 1.36 \\
Activity of ALT (IU/L) & $52.67 \mathrm{a}$ & $34.53 \mathrm{~b}$ & $43.53 \mathrm{ab}$ & 3.76 \\
\hline
\end{tabular}

$a, b, c$ : Values in the same row with different superscripts differ significantly $(P<0.05)$.

\section{Immune response of does and produced bunnies:}

Immunoglobulin (IgG and $\operatorname{IgM}$ ) concentration in blood serum of does and their offspring at the end of suckling period are presented in Table (6). Concentrations of IgG and IgM in serum of does and their offspring were higher in G3 drink magnetic water 3600 gauss, followed by G2 drink magnetic water 1200 gauss, while they lower in G1 drink tap water, but the differences were not significant. Concentrations of both IgG and IgM increased in serum of does than of offspring. Concentrations of both IgG and

IgM in serum of does was associated with globulin concentration in serum of does in all groups (Table 5). Contact of water with a permanent magnet for a considerable time produced magnetic charges and magnetic properties. Such magnetically treated water can decrease microbial load and improve the immune system (Lam, 2001).

\section{Litter size and mortality rate:}

Results in Table (7) showed significant differences $(\mathrm{P}<0.05)$ in litter size and mortality rate of bunnies among groups during different suckling intervals. Does in G2 drink magnetic water 1200 
gauss showed significantly $(\mathrm{P}<0.05)$ the highest litter size during the different suckling intervals, followed by those in G3 drink magnetic water 3600 gauss, while those in G1 drink tap water had the lowest values. The litter size of G2 and G3 increased by 6.67 and 3.33\% compared to G1, respectively. However, mortality rate revealed the opposite trend, which G1 showed significantly $(\mathrm{P}<0.05)$ the highest mortality rate, followed by G3, while G2 had the lowest rate. Mortality rate of young rabbit during suckling period decreased with advancing age as well as with increasing milk yield (Table 4). Mortality rate of $\mathrm{G} 2$ and $\mathrm{G} 3$ decreased by 5.46 and $2.80 \%$ compared with G1, respectively. These results agreed with those obtained by El-Hanoun et al. (2013) who found that exposure of water to the magnetic field increased $(\mathrm{P} \leq 0.05)$ litter size and number of kits born alive compared to those of does drank un magnetized water.

Table (6). Immunoglobulin concentration in blood serum of does and their offspring for the different groups.

\begin{tabular}{lccc}
\hline Item & \multicolumn{3}{c}{ Experimental group } \\
\cline { 2 - 4 } & G1 & G2 & G3 \\
\hline Does: & & & 4.26 \\
IgG (ng/ml) & 3.44 & 3.92 & 1.15 \\
IgM (ng/ml) & 0.93 & 1.07 & \\
Offspring: & & & 4.12 \\
IgG (ng/ml) & 2.62 & 3.67 & 1.18 \\
IgM (ng/ml) & 0.75 & 0.88 & \\
\hline
\end{tabular}

Table (7). Litter size / doe and mortality rate $(\%)$ in different groups during suckling period.

\begin{tabular}{|c|c|c|c|c|}
\hline \multirow{2}{*}{ Age (day) } & \multicolumn{3}{|c|}{ Experimental group } & \multirow{2}{*}{ MSE } \\
\hline & G1 & G2 & G3 & \\
\hline \multicolumn{5}{|l|}{ Litter size: } \\
\hline 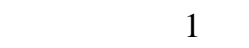 & $7.0 \mathrm{~b}$ & $7.4 \mathrm{a}$ & 7.2ab & 0.19 \\
\hline 7 & $6.6 b$ & $7.0 \mathrm{a}$ & $6.8 \mathrm{ab}$ & 0.13 \\
\hline 14 & $6.3 b$ & $6.7 \mathrm{a}$ & $6.5 \mathrm{ab}$ & 0.16 \\
\hline 21 & $6.1 b$ & $6.5 \mathrm{a}$ & $6.3 \mathrm{ab}$ & 0.14 \\
\hline 30 & $6.0 \mathrm{~b}$ & $6.4 \mathrm{a}$ & $6.2 \mathrm{ab}$ & 0.12 \\
\hline \multicolumn{5}{|c|}{ Mortality rate $(\%)$ : } \\
\hline $1-7$ & $5.71 \mathrm{a}$ & $5.41 b$ & $5.56 \mathrm{ab}$ & 0.09 \\
\hline $8-14$ & $4.55 \mathrm{a}$ & $4.29 b$ & $4.41 \mathrm{ab}$ & 0.08 \\
\hline $15-21$ & $3.17 \mathrm{a}$ & $2.99 \mathrm{~b}$ & $3.08 \mathrm{ab}$ & 0.07 \\
\hline $22-30$ & $1.64 \mathrm{a}$ & $1.54 \mathrm{~b}$ & $1.59 \mathrm{ab}$ & 0.06 \\
\hline $1-30$ & $14.29 \mathrm{a}$ & $13.51 \mathrm{~b}$ & $13.89 \mathrm{ab}$ & 0.12 \\
\hline
\end{tabular}

$a, b$ : Values in the same row with different superscripts differ significantly $(P<0.05)$.

\section{Litter weight and gain:}

Litter weight (LW) and their gain in different groups are shown in Table (8). The second group (G2) drink magnetic water 1200 gauss showed significantly $(\mathrm{P}<0.05)$ the highest litter weight and litter weight gain followed by G3 drink magnetic water 3600 gauss, while G1 had the lowest values. These results may be due to the higher milk yield for G2 compared to G1 as shown in Table (4). The litter weight of G2 and G3 at the weaning increased by 373 and $201 \mathrm{~g}$ or 15.32 and $8.26 \%$ compared to G1, respectively. The corresponding values for litter weight gain were 289 and $57 \mathrm{~g}$ or 14.01 and $2.76 \%$, respectively. The improved litter performance was concurred with increased milk yield and its contents of fat, lactose and consequently energy. These results agreed with those obtained by El-Hanoun et al. (2013) who found that exposure of water to the magnetic field increased $(\mathrm{P} \leq 0.05)$ litter weight at birth and at day 28 of age compared to those of does drank un magnetized water.

\section{Growth performance of bunnies:}

Data in Table (9) showed similar trends to litter weight and gain, which bunnies of G2 drink magnetic water 1200 gauss were significantly $(\mathrm{P}<0.05)$ the heaviest weights and gains at different times of the suckling period followed by those of G3 drink magnetic water 3600 gauss, while those of G1 drink tap water had the lightest weight and gain. These results may be due to the higher milk yield for G2 


\section{Ragab and Mahmoud}

compared to G1 as shown in Table (4). The bunnies weight of G2 and G3 at the weaning increased by 32.79 and $19.34 \mathrm{~g}$ or 8.08 and $4.77 \%$ compared to $\mathrm{G} 1$, respectively. The corresponding values for litter weight gain were 0.84 and $0.51 \mathrm{~g} /$ day or 7.16 and $4.34 \%$, respectively. The improved performance for growing rabbits, before and after weaning coming from does consumed magnetic water, showing the carry over effect of water type and magnetic treatments on their progeny performance. This could be explained by the improvements in health and immunity of the does as mentioned previously. Similar results were reported by Attia et al., (2011a, b, 2013). These improvements in progeny performance are in general agreement with those reported by Kronenberg (1993) and Lin (1995) who mentioned that magnetic water improved the performance of farm animals (chickens, turkeys, pigs, cows, calves and sheep).

Table (8). Litter weight and weight gain in different groups during suckling period.

\begin{tabular}{ccccc}
\hline \multirow{2}{*}{ Age (day) } & \multicolumn{4}{c}{ Experimental group } \\
\cline { 2 - 5 } Litter weight (g): & G1 & G2 & G3 \\
1 & $371 \mathrm{c}$ & $455 \mathrm{a}$ & $415 \mathrm{~b}$ & 26 \\
7 & $715 \mathrm{c}$ & $877 \mathrm{a}$ & $815 \mathrm{~b}$ & 49 \\
14 & $1139 \mathrm{c}$ & $1345 \mathrm{a}$ & $1263 \mathrm{~b}$ & 70 \\
21 & $1621 \mathrm{c}$ & $1895 \mathrm{a}$ & $1773 \mathrm{~b}$ & 82 \\
30 & $2434 \mathrm{c}$ & $2807 \mathrm{a}$ & $2635 \mathrm{~b}$ & 104 \\
Litter weight gain $(\mathrm{g})$ & & & $400 \mathrm{ab}$ & 40 \\
$1-7$ & $344 \mathrm{~b}$ & $422 \mathrm{a}$ & $448 \mathrm{ab}$ & 53 \\
$8-14$ & $424 \mathrm{~b}$ & $477 \mathrm{a}$ & $510 \mathrm{ab}$ & 34 \\
$15-21$ & $482 \mathrm{~b}$ & $541 \mathrm{a}$ & $862 \mathrm{ab}$ & 123 \\
$22-30$ & $813 \mathrm{~b}$ & $912 \mathrm{a}$ & $2220 \mathrm{~b}$ & 109 \\
$1-30$ & $2063 \mathrm{c}$ & $2352 \mathrm{a}$ & & \\
\hline
\end{tabular}

$a, b, c$ : Values in the same row with different superscripts differ significantly $(P<0.05)$.

Table (9). Average live body weight and gain of bunnies produced by does in different groups during suckling period.

\begin{tabular}{|c|c|c|c|c|}
\hline \multirow{2}{*}{ Age (day) } & \multicolumn{3}{|c|}{ Experimental group } & \multirow{2}{*}{ MSE } \\
\hline & G1 & $\mathrm{G} 2$ & G3 & \\
\hline \multicolumn{5}{|l|}{ Bunnies weight $(\mathrm{g})$ : } \\
\hline 1 & $53.05 b$ & $61.25 \mathrm{a}$ & $57.64 \mathrm{ab}$ & 1.12 \\
\hline 7 & $108.28 b$ & $125.28 \mathrm{a}$ & $119.87 \mathrm{ab}$ & 1.43 \\
\hline 14 & 180.80 & $202.14 \mathrm{a}$ & $194.28 \mathrm{ab}$ & 1.76 \\
\hline 21 & $265.78 b$ & $291.46 a$ & $281.43 \mathrm{ab}$ & 1.95 \\
\hline 30 & $405.73 b$ & $438.52 \mathrm{a}$ & $425.07 \mathrm{ab}$ & 2.24 \\
\hline \multicolumn{5}{|c|}{ Bunnies weight gain $(\mathrm{g})$ : } \\
\hline $1-7$ & $8.69 b$ & $9.14 \mathrm{a}$ & 9.89ab & 0.19 \\
\hline $8-14$ & $10.36 \mathrm{~b}$ & $10.98 \mathrm{a}$ & $10.63 \mathrm{ab}$ & 0.22 \\
\hline $15-21$ & $12.14 \mathrm{~b}$ & $12.76 \mathrm{a}$ & $12.45 \mathrm{ab}$ & 0.26 \\
\hline $22-30$ & $15.55 b$ & $16.34 \mathrm{a}$ & $15.96 \mathrm{ab}$ & 0.29 \\
\hline $1-30$ & $11.74 \mathrm{~b}$ & $12.58 \mathrm{a}$ & $12.25 \mathrm{ab}$ & 0.33 \\
\hline
\end{tabular}

$a, b, c:$ Values in the same row with different superscripts differ significantly $(P<0.05)$.

\section{Economic efficiency:}

Results in Table (10) showed that feed intake and feed cost was nearly similar for different groups. While, total cost (feed cost plus magnetic water cost) was higher significantly $(\mathrm{P}<0.05)$ for $\mathrm{G} 3$ drink magnetic water 3600 gauss followed by G2 drink magnetic water 1200 gauss, while G1 had the lower cost. The second group (G2) drink magnetic water 1200 gauss showed significantly $(\mathrm{P}<0.05)$ the highest price of weaning weight and net revenue followed by G3 drink magnetic water 3600 gauss, while G1 had the lowest values. Net revenue improved by $38.18 \%$ for G2, however decreased by $6.94 \%$ for G3 compared with G1, respectively. 
Table (10). Economic efficiency for the different groups.

\begin{tabular}{lcccc}
\hline \multirow{2}{*}{ Item } & \multicolumn{3}{c}{ Experimental group } & \multirow{2}{*}{ MSE } \\
\cline { 2 - 4 } & $\mathrm{G} 1$ & $\mathrm{G} 2$ & $\mathrm{G} 3$ & 0.19 \\
Feed intake (kg) & 13.07 & 13.12 & 12.97 & 0.57 \\
Feed cost (LE) & 39.20 & 39.35 & 38.91 & \\
Cost of magnetic water (LE) & 0 & 2 & 6 & $44.91 \mathrm{a}$ \\
Total cost (LE) & $39.20 \mathrm{~b}$ & $41.35 \mathrm{ab}$ & $2635.43 \mathrm{~b}$ & 103.57 \\
Weaning weight (g) & $2434.38 \mathrm{c}$ & $2806.53 \mathrm{a}$ & $60.61 \mathrm{~b}$ & 2.38 \\
Price of weaning weight (LE) & $55.99 \mathrm{c}$ & $64.55 \mathrm{a}$ & $15.70 \mathrm{~b}$ & 2.42 \\
Net revenue (LE) & $16.79 \mathrm{~b}$ & $23.20 \mathrm{a}$ & $-6.49 \mathrm{c}$ & 0.53 \\
Net revenue improvement \% & $00.00 \mathrm{~b}$ & $38.18 \mathrm{a}$ & & \\
\hline
\end{tabular}

$a, b, c:$ Values in the same row with different superscripts differ significantly $(P<0.05)$.

\section{CONCLUSION}

Based on the foregoing results, it could be concluded that doe rabbits drink magnetic water at 1200 gauss showed the best results concerning reproductive performance, milk yield and composition, blood parameters and immune response of balady rabbit does as well as the best results regarding litter size and weight, mortality rate and growth performance of their offspring and economic efficiency.

\section{REFERENCES}

Al-Mufarrej, S.; H.A. Al-Batshan; M.I. Shalaby and T.M. Shafey (2005). The effects of magnetically treated water on the performance and immune system of broiler chickens. International Journal of Poultry Science. 4: 96-102.

AOAC (1995). Official methods of analysis. $16^{\text {th }}$ Ed Association of official analytical chemists. Washington, DC, USA.

Attia, Y.A., E.A. Abd El Hamid, A.M. Ismaiel, and Asmaa S. El Nagar. 2013. The detoxication of nitrate by two antioxidants or a probiotic and the effects on blood and seminal plasma profiles and reproductive function of NZW rabbit bucks. Animal, 7:591-601.

Attia, Y.A.; A. Al-Hanoun and F. Bovera (2011a). Effect of different levels of bee pollen on performance and blood profile of New Zealand White bucks and growth performance of their offspring during summer and winter months. Journal Animal Physiology and Animal Nutrition, 95: 17-26.

Attia, Y.A.; A. Al-Hanoun; A.E. Tag El-Din; F. Bovera and E. Shewika (2011b). Effect of bee pollen levels on productive, reproductive and blood traits of NZW rabbits. J. Journal Animal Physiology and Animal Nutrition, 95:294-303.

Bergsrud, F. and J. Linn (1990). Water quality for livestock and poultry. Minnesota Extension Service Publication AG-FO-1864-D

De Blas, J.C. (2013). Nutritional impact on health and performance in intensively reared rabbits. Animal, 7 s1: $102-111$.

El-Hanoun A.M., Y.A. Attia, A. E. Abd El-Hamid, H.A. Gad and M.M. Abdella (2013). Response of rabbit does to water type and magnetic treatments. Proceeding of the $4^{\text {th }}$ scientific conference of Animal Production Research Institute, November 12-13th, 2013, Dokki, Giza, Egypt.

Hozayn, M. and A.M.S. Abdul Qados (2010). Magnetic water application for improving wheat (Triticum aestivum L.) crop production. Agric. Biol. J. N. Am., 1(4): 677-682.

IBM SPSS Statistics 22 (2013). Statistical package for the social sciences, Release 22, SPSS INC, Chicago, USA. 


\section{Ragab and Mahmoud}

Khudiar, K.K. and A.M. Ali (2012). Effect of magnetic water on some physiological aspects of adult male rabbits. Proceeding of the Eleventh Veterinary Scientific Conference, 2012; 120-126.

Kronenberg, K.J. (1985). Experimental evidence for effects of magnetic fields on moving water. IEEE Transaction on Magnetics, 21:2059-2061.

Kronenberg, K.J. (1993). Magnetized II: More alluring facts about treating water with magnets. Aqua Magazine, September, 20-24.

Lam, M. (2001). Magnetized water. (www.DrLam.com)

Lardy, G. and C. Stoltenow (1999). Livestock and water. North Dakota State University, (NDSU Extension Service).

Lin, I. and J. Yotvat (1989). Exposure of irrigation water to magnetic field with controlled power and direction: effects on grapefruit. Alon Hanotea, 43: 669-674.

Lin, I.J. (1995). Magnetised water is no mystery. Alive, 148:12-14.

Marai, I.F.M.; A.A. Habeeb and A.E. Gad (2005). Tolerance of imported rabbits grown as meat animals to hot climate and saline drinking water in the subtropical environment of Egypt. Animal Science, 81: 115-123.

Mg-Therapy (2000). Magnetic water. http://www. Thepainrelivers. Com.au/aboutmagnetic-therapy-painrelife.php.

NRC (1977). Nutrients Requirements of Domestic Animals. Nutrients Requirements of Rabbits. $2^{\text {nd }}$ Edition. National Research Council, National Academy of Science. Washington, DC. USA.

Sargolzehi, M.M.; M. Rezaee Rokn-Abadi and A.A. Naserian (2009). The effects of magnetic water on milk and blood components of lactating Saanen goats. International Journal of Nutrition and Metabolism, 1: 20-24.

Skeldon, P. (1990). Green descaling with black magic. Process Eng., London, 71(7):57.

Sunmonu, T.O. and O.B. Oloyede (2007). Biochemical assessment of the effect of ceude oil contaminated catfish (Clarias gariepinus) on the hepatocytes and performance of rate. African Journal of Biochemistry Research, 1:83-89.

Tkachenko, Y. and N. Semyonova (1995). Your way to health: Magnetic water plus separate nutrition" In: Mysteries of Magnetic Energies A Collection of Scientific Works on the Usage of Magnetic Energies in Medical Practice. Yuri P. Tkachenko (ed), Printing Emirates, Printing \& PublishingSharjah, UAE. 1995. Part 6, pp: 225-244.

Verma, S.S. (2011). Magnetic water treatment. Chemical Business Jurnal, 13-16. 


\author{
آيات عبدالمقصود رجب و ياسمين عحم محمود \\ معهل بحوث الاتتاج الحيوانى - مركز البحوث النزراعية - الدقى - الجيزة معرد
}

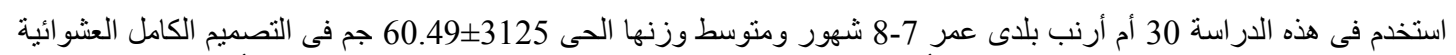

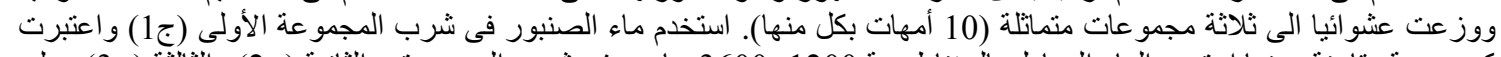

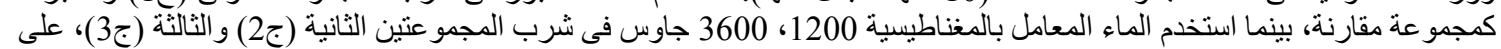
التو الىى. عذيت الأرانب فى كل المجمو عات على عليقة الأرانب التجارية.

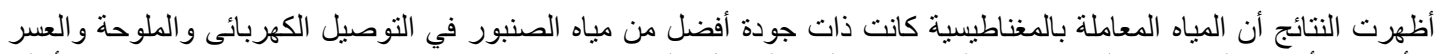

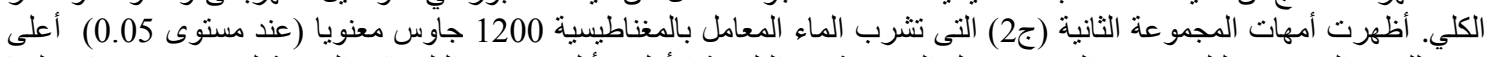

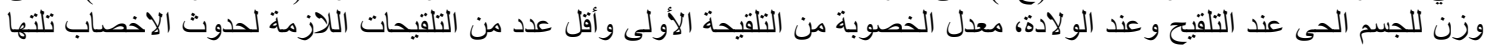

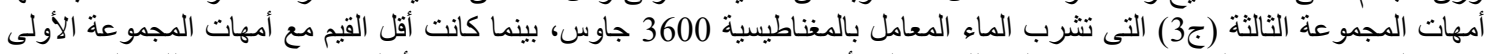

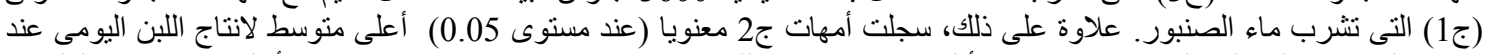

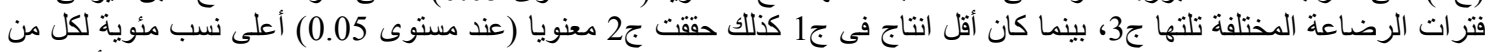

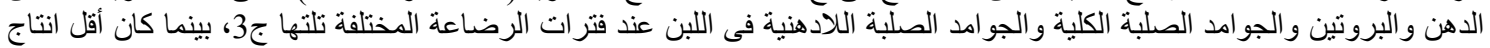

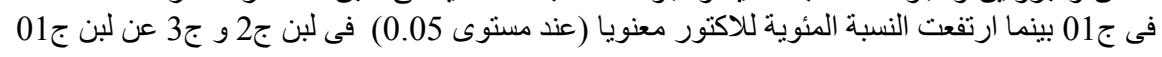

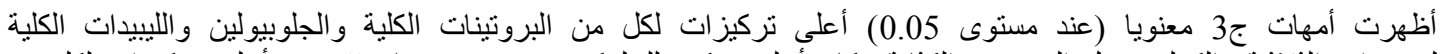

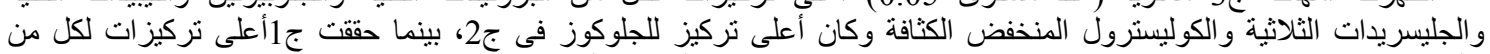

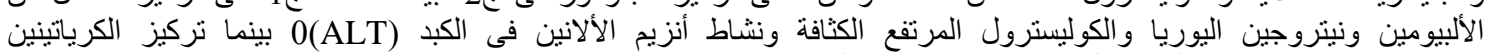

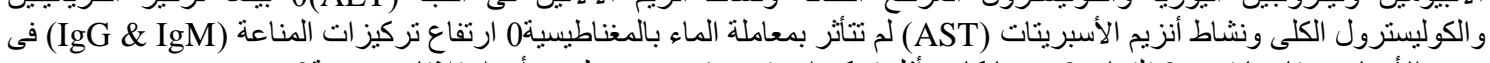

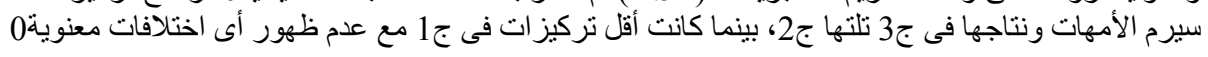

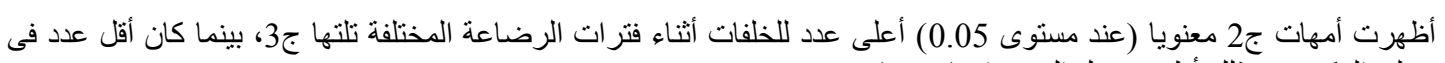
ج01 على العكس من ذلك أظهر معدل النفوق اتجاه مضاد.

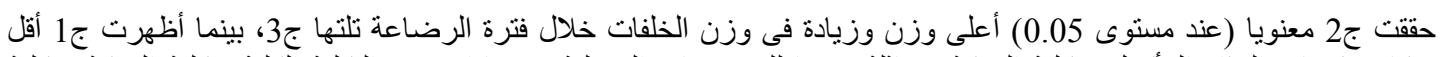

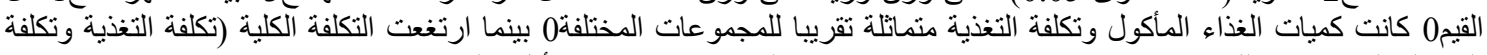

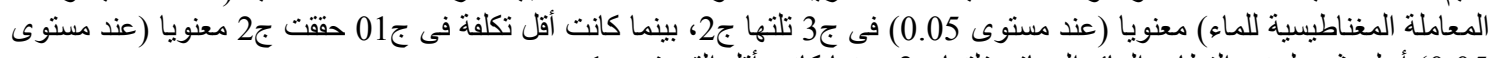

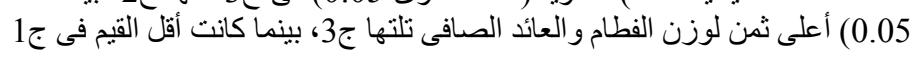

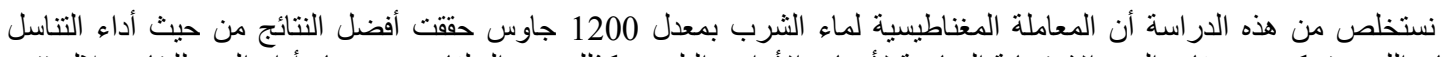

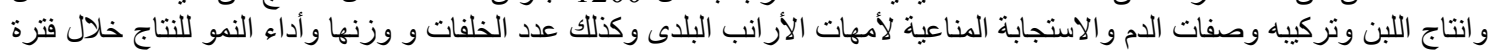
الرضاعة والكفاءة الاقتصادية. 